\begin{tabular}{ll|l} 
Volume & $: 5$ & E-ISSH: 2656-940X \\
Nomor & $: 4$ & P-ISSH: 2442-367X \\
Bulan & $:$ November & U-I \\
Tahun & $: 2019$ & URL:jurnal.ideaspublishing.co.id
\end{tabular}

\title{
Efektivitas Penggunaan Media Gambar \\ dalam Meningkatkan Keaktifan Siswa \\ pada Pembelajaran IPS
}

\author{
Beatus Mendelson Laka ${ }^{1}$, Patma Tuasikal ${ }^{2}$ \\ Sekolah Tinggi Keguruan dan Ilmu Pendidikan Biak \\ surel: lakamendelson@gmail.com
}

DOI: 10.32884/ideas.v5i4.220

\begin{abstract}
Abstrak
Tujuan penelitian ini untuk menganalisis efektivitas penggunaan media gambar dalam meningkatkan keaktifan siswa di SD Negeri Sopen Kabupaten Biak Numfor Provinsi Papua. Jenis penelitian ini adalah penelitian kualitatif dengan pendekatan fenomenologi. Teknik pengumpulan data dilakukan dengan menggunakan tiga cara yaitu observasi yang tidak terstruktur, wawancara mendalam, dan studi dokumentasi. Teknik analisis data yang digunakan yaitu dengan alur, yang meliputi reduksi data, penyajian data, dan tahap verifikasi. Hasil penelitian ini menunjukkan bahwa penggunaan media gambar sangat membantu guru dalam penerapan pembelajaran di kelas. Hal ini membuktikan bahwa media gambar merupakan salah satu alat peraga yang sangat membantu guru.
\end{abstract}

Kata kunci: efektivitas, media gambar, IPS

\section{Pendahuluan}

Sekolah dasar merupakan tumpuan awal siswa meneruskan cita-cita dalam dunia pendidikan. Namun, proses pembelajaran yang selalu digunakan oleh guru di dalam kelas sering membuat siswa bosan. Hal ini disebabkan karena penggunaan media dan metode yang belum tepat. Di sinilah guru seharusnya kreatif dalam meningkatkan kualitas pembelajaran pada tingkat sekolah dasar, karena keberhasilan siswa di bangku sekolah dasar merupakan suatu tumpuan bagi pengembangan kreativitas dan efektivitas siswa itu sendiri.

Seiring dengan pesatnya perkembangan media informasi dan komunikasi, baik perangkat keras (hardware) maupun perangkat lunak (software) akan membawa perubahan, yaitu bergesernya peranan guru termasuk guru IPS sebagai penyampai pesan/informai. Guru tidak lagi sebagai satu-satunya sumber informasi dalam pembelajaran karena siswa dapat memperoleh informasi dari berbagai sumber, misalnya buku literatur, TV, siaran radio, surat kabar, dan majalah, bahkan dari jaringan internet seperti media social atau google yang saat ini populer. Oleh karena itu, saat ini sangat dibutuhkan pembelajaran yang inovatif sehingga efektif.

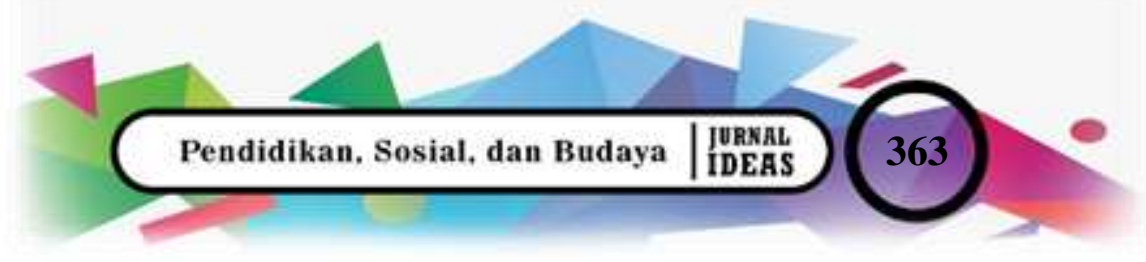




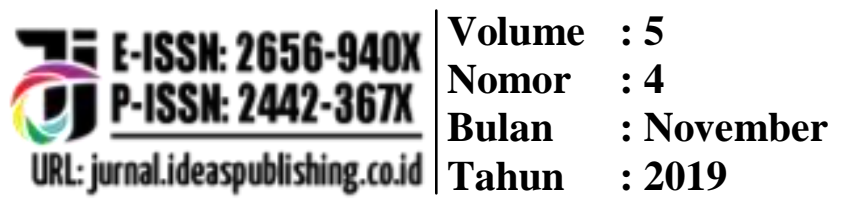

Untuk mewujudkan pembelajaran yang efektif membutuhkan model yang sesuai dengan karakteristik siswanya. Model pembelajaran sendiri, menurut Rusman adalah suatu rencana atau pola yang dapat digunakan untuk membentuk kurikulum (rencana pembelajaran jangka panjang), merancang bahan-bahan pembelajaran, dan membimbing pembelajaran di kelas atau yang lain (Rusman, 2013:144). Proses pembelajaran tidak akan berhasil apabila pembelajaran tidak menggunakan strategi, media, model, dan metode yang tepat serta sesuai dengan tuntutan siswa sehingga materi pelajaran dengan mudah dipahami oleh siswa. Dalam penerapannya, media akan menghambat proses pembelajaran yang akan mengakibatkan waktu dan tenaga guru.

Pembelajaran di dalam ruang kelas yang efektif membutuhkan komitmen profesional guru. Salah satu pembelajaran yang efektif yaitu dengan menggunakan media gambar sehingga pembelajaran akan menarik bagi siswa. Penggunaan media yang tepat dapat memberikan kesempatan kepada siswa untuk aktif dalam proses pembelajaran sehingga mereka lebih memahami dan mendalami materi yang diajarkan.

Berdasarkan observasi dalam pembelajaran di kelas IV SD Negeri Sopen Kabupaten Biak Numfor Provinsi Papua ditemukan dalam penerapan pembelajaran guru tidak menggunakan media dalam pembelajaran. Hal ini diperkuat dengan hasil wawancara langsung peneliti dengan kepala sekolah terkait dengan pembelajaran yang dilakukan oleh guru selalu memberikan ceramah kepada siswa, sehingga siswa tidak aktif dalam proses pembelajaran di kelas.

Maftukhah dkk., (2012) dalam penelitiannya menjelaskan ada beberapa faktor yang mempengaruhi hasil belajar IPS yaitu (1) kemampuan siswa (61,55\%); (2) kemampuan guru (66,75\%); (3) sarana penunjang (77,00\%); (4) dukungan sekolah (72,67\%); (5) dukungan keluarga (62,00\%). Dari hasil penelitian ini, dapat diketahui bahwa kemampuan siswa merupakan faktor yang paling dominan berpengaruh terhadap belajar siswa. Kemampuan siswa menjadi fokus utama dalam pencapaian tujuan pembelajaran IPS baik di sekolah maupun dalam kehidupan siswa yaitu memiliki kemampuan dasar berpikir logis dan kritis, rasa ingin tahu, inkuiri, memecahkan masalah, dan keterampilan dalam kehidupan (Kemendikbud, 2014). 


\begin{tabular}{ll|l} 
Volume & $: 5$ & E-ISSH: 2656-940X \\
Nomor & $: 4$ & P-ISSH: 2442-367K \\
Bulan & $:$ November & URL \\
Tahun & $: 2019$ & URL:jurnal.ideaspublishing.co.id
\end{tabular}

\section{Metode}

Jenis penelitian ini adalah penelitian kualitatif dengan pendekatan fenomenologi. Melalui pendekatan fenomenologi, peneliti mencoba mengamati dan menjelaskan serta mengungkap makna dari peristiwa-peristiwa atau fenomena lapangan sehingga dapat dilakukan analisis tentang efektivitas penggunaan media gambar dalam meningkatkan keaktifan siswa kelas IV pada pembelajaran IPS di SD Negeri Sopen Distrik Biak Barat Kabupaten Biak Numfor Provinsi Papua.

Penelitian dilakukan di SD Negeri Sopen Distrik Biak Barat Kabupaten Biak Numfor Propinsi Papua. Lokasi ini dipilih menjadi lokasi penelitian karena SD Negeri Sopen pada aspek pembelajarannya, guru masih monoton dalam penerapan proses pembelajaran di sekolah.

Subjek penelitian ini adalah kepala sekolah dan guru SD Negeri Sopen Distrik Biak Barat Kabupaten Biak Numfor Provinsi Papua. Dalam menentukan subjek penelitian, digunakan sampel bertujuan (purposive sampling). Teknik sampling tidak berdasarkan probabilitas, melainkan dipilih untuk mendeskripsikan situasi sosial yang terkait dengan masalah yang diteliti atau sampel bertujuan dengan menciptakan informan kunci (key informan), selanjutnya ditetapkan sampel secara bergulir sesuai dengan kebutuhan penelitian atau kebutuhan data yang diperlukan.

Data dari penelitian ini berupa ungkapan atau kata-kata, gambaran fakta lapangan yang seluruhnya diperoleh dari para informan, lembar observasi dan dokumen dari sekolah. Sumber data dalam penelitian ini adalah kepala sekolah, guru, dan siswa SD Negeri Sopen Distrik Biak Barat Kabupaten Biak Numfor Provinsi Papua.

Teknik pengumpulan data dalam penelitian ini dengan menggunakan tiga cara yaitu sebagai berikut.

a Observasi yang tidak terstruktur yaitu dalam melakukan pengamatan peneliti tidak mengunakan instrumen yang telah baku, tetapi hanya berupa rambu-rambu pengamatan. Dalam kegiatan observasi ini peneliti mengamati dan melihat objek yang diteliti yaitu gaya mengajar guru yang masih monoton, sehingga peneliti dapat langsung menganalisis, menafsirkan, dan menyimpulkan data yang telah dikumpulkan.

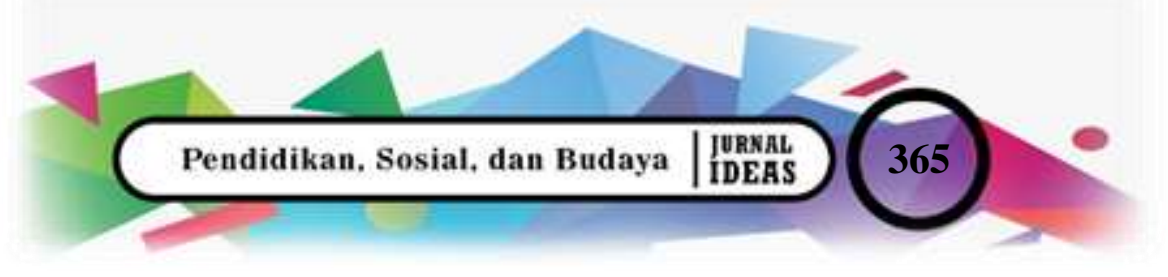




\section{GE E-ISSH: 2656-940X $\mid$ Volume : 5 \\ P-ISSN: 2442-367X Nomor : 4 \\ URL: jurnal.ideaspublishing.co.jd Tahun : 2019}

b. Wawancara mendalam bertujuan untuk memperoleh bentuk-bentuk informasi dari semua informan, tetapi susunan kata dan urutannya disesuaikan dengan ciri-ciri setiap responden, teknik bersifat luwes, susunan pertanyaan dan susunan katakatanya dalam setiap pertanyaan dapat berubah-ubah pada saat wawancara disesuaikan dengan kondisi subjek penelitian (informan). Pada saat peneliti melakukan wawancara, peneliti dipandu dengan pedoman wawancara (interview guide) dan dibantu alat perekam suara, alat pencatat (buku dan pena). Semua informasi dicatat secara teliti dan cermat dan selalu dikonfirmasi ulang apabila masih ada yang kurang jelas, sehingga data yang didapat sesuai kebutuhan. Teknik wawancara mendalam ini digunakan untuk menggali data yang bersumber dari Kepala SD Negeri Sopen Distrik Biak Barat Kabupaten Biak Numfor Provinsi Papua yang berhubungan dengan kebijakan dan langkah-langkah yang ditempuh dalam proses pembelajaran.

c. Studi dokumentasi yaitu dalam prosesnya, peneliti menggunakan alat teknologi handphone kamera untuk mendokumentasikan hasil pengumpulan data berupa foto kegiatan selama wawancara dan bukti-bukti dokumen yang telah diarsipkan berupa kebijakan dan langkah-langkah yang ditempuh oleh Kepala SD Negeri Sopen dalam pembelajaran guru di kelas.

Teknik analisis yang digunakan dalam penelitian ini, yaitu dilakukan dengan alur yang meliputi reduksi data, penyajian data, dan tahap verifikasi. Model analisis data tersebut dapat digambarkan, seperti terdapat pada gambar berikut.

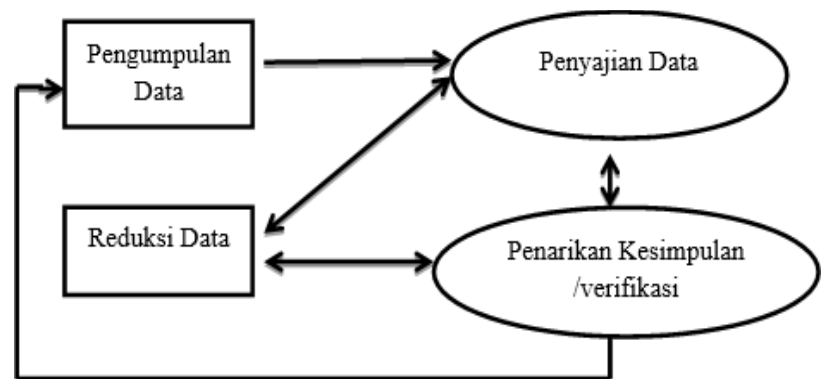

Gambar 1 Teknik Analisis Data Kualitatif

(Miles and Huberman dalam Sugiyono, 2014: 405)

Pengujian kredibilitas data dilakukan dengan pendekatan triangulasi. Menurut Fraenkel dan Wallen (Sugiyono, 2014: 439) triangulasi dalam pengujian ini diartikan 


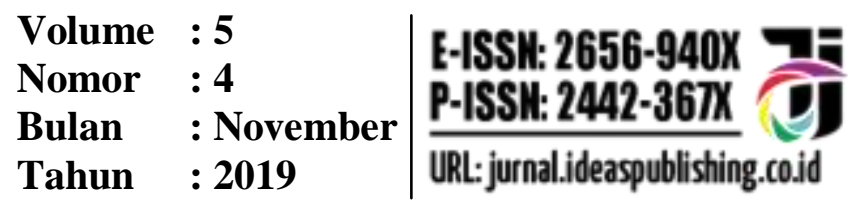

sebagai pengecekan data dari berbagai sumber dengan berbagai cara dan berbagai collecting data.

\section{Hasil dan Pembahasan}

Berdasarkan wawancara peneliti bersama para guru di SD Negeri Sopen pada tanggal, 12 Juli 2019 diketahui bahwa guru di SD Negeri Sopen jarang menggunakan media gambar. Hal ini seperti yang dituturkan oleh Dance Sopenbaken, S.Pd. dan Maks Abidondifu, S.Pd. berikut ini.

"Adapun kalau digunakan pada saat dibutuhkan, kadangkala melibatkan siswa kadang kala tidak." (Sopenbaken, 2019)

"Guru SD Negeri Sopen sangat mengharapkan bimbingan dan pelajaran agar mareka mempunyai pemahaman dan pengetahuan yang mendalam terhadap penggunaan media gambar pada peroses belajar mengajar." (Abidondifu, 2019)

Meskipun demikian pengunaan media gambar oleh guru SD Negeri Sopen dapat dikatakan belum maksimal, namun guru tersebut tidak berupaya dan berusaha untuk membuat media gambar semampunya. Berdasarkan hasil wawancara peneliti dengan kepala sekolah SD Negeri Sopen secara umum dapat diketahui bahwa rata-rata guruguru SD Negeri Sopen pernah mengikuti seminar/penataran. Sekolah juga telah menyediakan buku panduan meskipun hal ini masih minim. Akan tetapi guru-guru masih merasa sulit untuk menerapkan pembelajaran dengan menggunakan media gambar walaupun sederhana, murah, dan terjangkau.

Pada kesempatan ini peneliti melaksanakan pembelajaran dengan menggunakan media gambar di kelas IV sebagai contoh pembelajaran menggunakan media gambar pada materi keanekaragaman suku bangsa di Indonesia. Setelah selesai pembelajaran, respons dari para guru yang melihat secara langsung tertarik dengan penggunaan media gambar yang ditampilkan peneliti. Hal ini diakibatkan karena semua guru yang ada di SD Negeri Sopen adalah guru yang sudah kalah dalam usia (tua).

Sementara dari sisi sarana prasarana, SD Negeri Sopen sudah memenuhi standar, namun yang perlu dibenahi dari sisi sumber daya manusia karena rata-rata sumber daya manusia yang dimiliki oleh sekolah tersebut masih kurang. Jumlah guru yang ada di SD Negeri Sopen berjumlah 4 orang, Aparatur Sipil Negara 3 orang, dan 1 orang guru

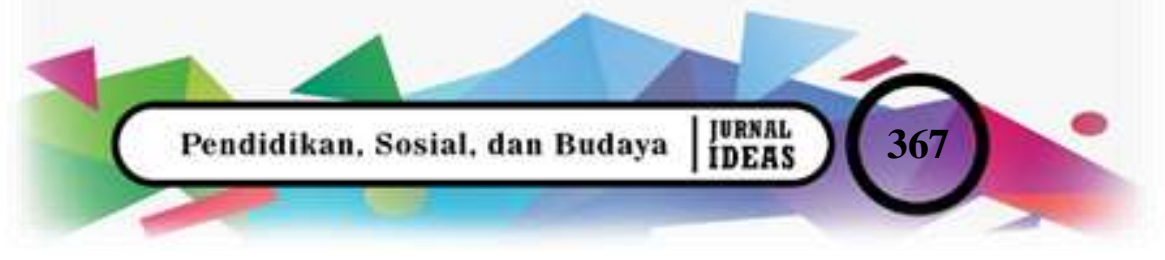




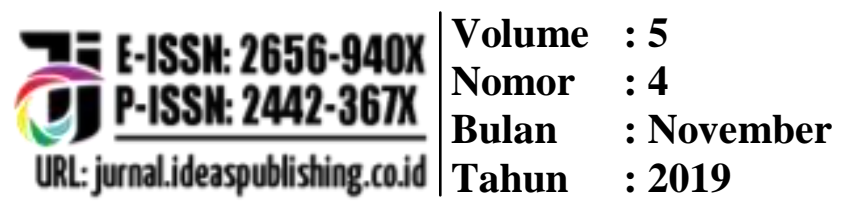

honorer. Guru honorer ini juga selain guru beliau sebagai operator dapodik. Semua guru berjenis kelamin laki-laki. Dengan demikian harus ada penambahan guru yang masih muda agar ada kolaborasi dalam penerapan pembelajaran di kelas serta diharapkan untuk mengetahui tentang cara yang terbaik dalam meningkatkan mutu pembelajaran, dengan menggunakan media gambar. Agar pembelajaran efektif, maka diperlukan peran aktif dari pihak sekolah dan stakeholder dalam memberikan pelatihan dan workshop kepada guru-guru yang ada di sekolah.

Sedangkan dari sisi pengawasan kepala sekolah, dapat diketahui memang jarang mengadakan pengawasan karena adanya tugas yang harus diselesaikan. Namun kepala sekolah sudah memberikan wewenang kepada wakil kepala sekolah untuk melaksanakan pengawasan dan supervisi dalam kegiatan peroses pembelajaran yang dilakukan oleh guru-guru di sekolah tersebut. Dari hal di atas dapat disimpulkan bahwa kurang ketatnya pengawasan dari atasan ternyata juga dapat mengurangi optimalnya kegitan pembelajaran.

Hal lain yang juga terjadi yaitu kurang maksimalnya pengawasan dari dinas pendidikan Kabupaten. Pengaasan terutama terkait penempatan dan pemerataan distribusi guru di sekolah-sekolah. Dengan adanya penawasan, maka diharapkan tidak adanya sekolah yang kekurangan guru. Dapat disimpulkan bahwa pengawasan turut membentuk dan memotivasi guru untuk melaksanakan tugasnya dengan baik dan optimal. Sehingga efektivitas penggunaan media gambar dalam pembelajaran IPS di SD Negeri Sopen dapat terlaksana dengan baik sesuai dengan tujuan pembelajaran yang telah dirumuskan dan diharapkan.

Pada saat yang bersamaan, peneliti juga melakukan wawancara dengan siswa kelas IV SD Negeri Sopen terkait dengan efektivitas penggunaan media gambar yang diterapkan pada saat proses pembelajaran di kelas. Chena Wanma, Evan Miosido, dan Muktar Rumbiak, seorang siswa di SD Sopen mengatakan,

"Pak Guru, kalau belajar pakai media ini bagus. Kami cepat mengerti dan tangkap apa yang pak guru jelaskan." (Wanma, 2019)

"Pak guru saya jadi mengerti tentang apa yang pak guru jelaskan tadi dan saya tau ternyata Indonesia kaya akan adat dan budaya." (Miosido, 2019)

"Ternyata saya baru tau kalau di Papua juga memiliki banyak adat dan budaya." (Rumbiak, 2019) 


\begin{tabular}{ll|l} 
Volume & $: 5$ & E-ISSH: 2656-940X \\
Nomor & $: 4$ & P-ISSH: 2442-367K \\
Bulan & $:$ November & URL \\
Tahun & $: 2019$ & URL:jurnal.ideaspublishing.co.id
\end{tabular}

Ketika ditanyakan apakah selama ini ada guru yang mengajar menggunakan media kepada mereka, serentak mereka menjawab belum pernah. Pada dasarnya guru harus melakukan pembelajaran di kelas secara bervariasi. Hal ini dilakukan agar siswa tidak bosan dalam menerima pelajaran dari guru. Untuk mempermudah proses pembelajaran, sebaiknya guru memiliki kreativitas untuk membuat media yang menarik, karena dengan menggunakan media yang menarik, maka sudah tentu siswa akan memiliki niat baik untuk menerima pelajaran.

Guru yang ada di SD Negeri Sopen mengakui dengan jujur kekurangan mereka terkait dengan penggunaan media dalam proses pembelajaran di kelas. Namun yang sangat menarik dari kejujuran para guru tersebut, mereka sangat terbuka untuk menerima masukan dari peneliti. Rekomendasi yang disampaikan oleh peneliti bukan sekedar disampaikan secara lisan saja tetapi juga melalui praktik penerapan pembelajaran dengan menggunakan media gambar.

Penggunaan media gambar akan menarik siswa untuk belajar seperti yang disampaikan oleh Oemar Hamalik (dalam Azhar Arsyad, 2011: 2) yang menjelaskan bahwa untuk mewujudkan pembelajaran menarik, seharusnya menggunakan alat-alat yang dapat disediakan oleh sekolah dan tidak tertutup kemungkinan bahan alat-alat tersebut sesuai dengan perkembangan dan tuntutan zaman. Guru sekurang-kurangnya dapat menggunakan alat yang murah dan efisien. Meskipun media yang digunakan sederhana dan bersahaja tapi merupakan keharusan dalam upaya mencapai tujuan pembelajaran yang diharapkan. Disamping mampu menggunakan alat-alat yang tersedia, guru juga dituntut untuk dapat mengembangkan keterampilan membuat media pembelajaran yang akan digunakannya apabila media tersebut belum tersedia.

\section{Simpulan}

Dari hasil penelitian dan analisis data yang telah di bahas pada bab sebelumnya, maka dapat ditarik beberapa kesimpulan sebagai berikut. Kurangnya kemampuan guru dalam menggunakan media gambar dengan bentuk yang bervariasi. Kurangnya minat guru dalam mempergunakan media, dalam hal ini media gambar terlihat jarang guru

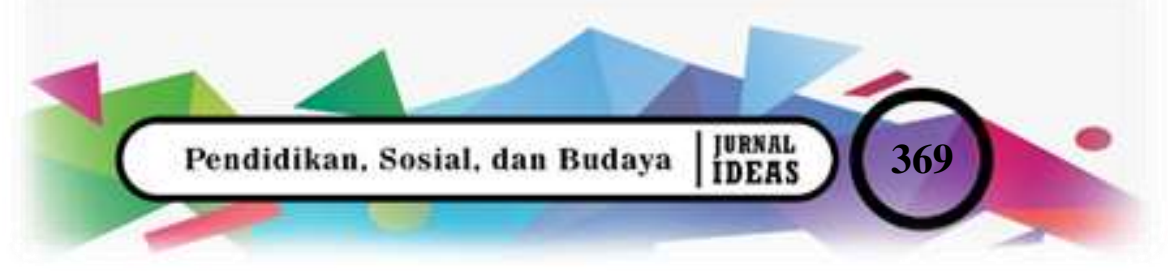




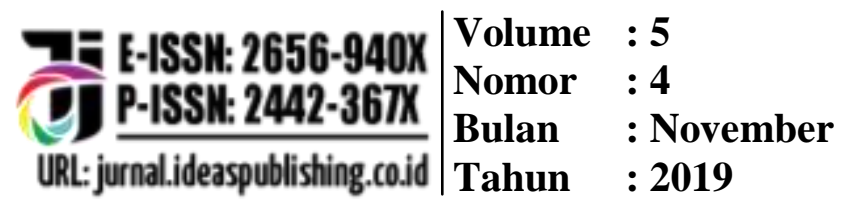

mengadakan penilaian terhadap media gambar tersebut. Kurangnya usaha guru untuk membuat media gambar yang belum tersedia di Sekolah Dasar.

\section{Daftar Pustaka}

Abidondifu, Maks. (2019, Juli). Media Gambar dalam Pembelajaran. (B.M. Laka, Interviewer).

Daryanto. (2011). Media Pembelajaran. Bandung: Satu Nusa.

Kemendikbud. (2014). Permendikbud Nomor 58 Tahun 2014 tentang Panduan Pengembangan Materi Pembelajaran pada Kurikulum. Jakarta: Kementerian Pendidikan dan Kebudayaan.

Maftukhah, L., Harnanik, H., \& St. Sunarto, S.S. (2012). Faktor-Faktor yang Mempengaruhi Kesulitan Belajar IPS Terpadu Kelas VII di SMP Negeri 1 Plantungan Kabupaten Kendal. Economic Education Analysis Journal, 1(2). Retrieved from https://journal.unnes.ac.id/sju/index.php/eeaj/article/view/549.

Miosido, Evan. (2019, Juli). Efektivitas Penggunaan Media Gambar. (B.M. Laka, Interviewer).

Rumbiak, Muktar. (2019, Juli). Efektivitas Penggunaan Media Gambar. (B.M. Laka, Interviewer).

Rusman. (2013). Model-Model Pembelajaran. Jakarta: Raja Grafindo Persada. Sugiyono, (2014). Metode Penelitian Manajemen. Bandung: Alfabeta.

Sopenbaken, Dance. (2019, Juli). Media Gambar dalam Pembelajaran. (B.M. Laka, Interviewer).

Wanma, Chena. (2019, Juli). Efektivitas Penggunaan Media Gambar. (B.M. Laka, Interviewer). 